\title{
Correction: Not just another ACL paper: the importance of 'Outcomes of single bundle arthroscopic anterior crucial ligament reconstruction in a limited resource setting'
}

Koh JL. Not just another ACL paper: the importance of 'Outcomes of single bundle arthroscopic anterior crucial ligament reconstruction in a limited resource setting'. J ISAKOS 2021;6:185-6.

In the above article, it was incorrectly written that there is a single orthopaedic centre in the country, and that patients who can afford care often must seek it outside of the country. The article is based on a single government hospital experience where economically poor patients come for treatment; orthopaedic surgeons in multiple centres perform ACL surgery in Nepal and occasional complex patients seek care in India.

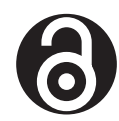

\section{OPEN ACCESS}

Open access This is an open access article distributed in accordance with the Creative Commons Attribution Non Commercial (CC BY-NC 4.0) license, which permits others to distribute, remix, adapt, build upon this work noncommercially, and license their derivative works on different terms, provided the original work is properly cited, an indication of whether changes were made, and the use is non-commercial. See: http://creativecommons.org/licenses/by-nc/4.0/.

(C) International Society of Arthroscopy, Knee Surgery and Orthopaedic Sports Medicine 2021. Re-use permitted under CC BY-NC. No commercial re-use. Published by BMJ.

J ISAKOS 2021;6:318. doi:10.1136/jisakos-2020-000580corr1

D Check for updates 